\title{
TAX MORALITY: EXAMINING THE BEPS DEBATE, WORK OF THE OECD AND ITS IMPACT ON AFRICA
}

\author{
by Daniel Godson Olika*
}

\section{Introduction}

International tax issues have never been at the forefront of international politics as they are today. ${ }^{1}$ This is due in large part to the realization that the current international tax system in existence allows multinational corporations to plan their taxes in such a way that they will be able to pay little or no taxes at all. They are able to do this through certain loopholes and gaps that currently exist in the system. These loopholes and gaps are seen as creating opportunities for taxpayers who are involved in cross-border activities to aggressively structure their activities to mitigate potential tax exposure or achieve no tax liabilities. ${ }^{2}$ They do this by exploiting; the hybrid-mismatch arrangements, shortcomings of the transfer pricing rules in jurisdictions where they operate and shifting profits from countries where their profits are made to countries with low tax rates. ${ }^{3}$ Consequently, some multinationals pay as little as five percent in corporate taxes, even as smaller domestic businesses pay up to 30 percent. ${ }^{4}$ The result of this activity is what is known as; base erosion and profit-shifting (BEPS) and it has the potential to deprive all countries of significant tax revenues. ${ }^{5}$ It is worthy to note that this problem is not new at all as it has been in existence for a long time now. What is new however; is the attention it is getting from both the media and policy makers alike. This has led to an intense debate between both the media and policy makers as to whether the international tax planning activities of multinationals is moral.

It should be borne in mind that the tax planning strategy of multinationals is tantamount to tax avoidance and therefore not

* $\quad$ LLB (Hons) University of Lagos.

1 KPMG 'Don't underestimate BEPS' impact on indirect tax' https:// assets.kpmg.com/content/dam/kpmg/pdf/2016/06/global-indirect-tax-beps.pdf (accessed 23 February 2017).

2 Deloitte "Changing international tax landscape: Local impact of base erosion and profit shifting (BEPS) project' https://www2.deloitte.com/ng/en/pages/tax/ articles/local-impact-base-erosion-profit-shifting-abti-tax-avoidance.html (accessed 23 February 2017).

3 J Zeder "Making international tax laws just: Professor Diane King gives voice to emerging nations' concerns' https://www.lawmagazine.bc.edu/2015/02/makinginternational-tax-laws-just/ (accessed 24 February 2017).

4 Zeder (n 3 above).

5 Zeder (n 3 above). 
illegal. This principle is a trite principle of tax law and was elucidated by the Nigerian Supreme Court in Federal Board of Inland Revenue $v$ American International Insurance Company Nigeria Plc: ${ }^{6}$

Tax is an obligation not a duty. One is not a bad citizen if one can organise his business or trade in a legal manner to minimise his tax liability. He could and he should resist within legal means any unduly wide interpretation or unconventional implication of legislative intent of a tax law that might increase that burden. He can do so without being ashamed of walking in the street as a patriotic citizen. A shrewd business acumenship and a legitimate protection of sweat of labour are not a dishonest act or an act having any moral turpitude. It is pragmatic and practical. Being capitalistic might leave much to be desired but among what is left is not illegality.

Whilst this position of the law is easily understood by tax experts, policy makers, business men and lawyers; this principle is neither easily understandable nor easily explainable to the public especially when considered against the backdrop of how much countries lose to this tax planning strategy. An estimate of between US $\$ 100$ Billion and US $\$ 200$ Billion is lost annually due to BEPS and this equates to between four percent and ten percent of global revenues from corporate income tax. ${ }^{7}$ These statistics further compound the problem of the BEPS debate and makes the legality of the tax planning strategy of multinational corporations difficult for the public to swallow.

This rave debate and harsh criticism from the public influenced the intervention of the Organisation for Economic Co-operation and Development (OECD) to start its now famous BEPS Project. The OECD BEPS Project aims to provide governments or tax administrators with clear international solutions for fighting aggressive corporate tax planning strategies that artificially shift profits to locations where they are subjected to more favourable tax treatment. ${ }^{8}$ Consequently, in 2015, the OECD released the final draft of its 15 action plans to help address the problem of base erosion and profit-shifting. This project has been received differently by various stakeholders and jurisdictions. For instance, its impact on Africa and how African nations will react to the project has been the subject of intense debate. This paper shall address the various strands of the BEPS debate, the OECD BEPS project, the impact of the project in Africa and Nigeria. The next section shall address the various strands of the debate.

6 [1999] 1 NLRN 50.

7 L Brunto 'The OECD/G20 base erosion and profit shifting (BEPS) project - an informed perspective' https://www.cliffedekkerhofmeyr.com/en/news/publica tions $/ 2015 /$ tax/tax-alert-16-october-the-oecdg20-base-erosion-and-profit-shift ing-beps-projectan-informed-perspective.html (accessed 23 February 2017). 


\section{Morality and legality: The twin perspectives to the base erosion and profit-shifting (BEPS) debate}

The Courts have from time immemorial stated that tax avoidance is neither immoral nor illegal. ${ }^{9}$ This position was aptly captured by the UK Court in Levene $v I R C,{ }^{10}$ where the Court stated that:

No man in this country is under the smallest obligation, moral or otherwise, to arrange his legal relations to his business or to his property so as to enable the Inland Revenue to put the largest possible shovel into his stores. The Inland Revenue is not slow - and quite rightly - to take advantage, which is open to it under the taxing Statutes for the purpose of depleting the taxpayer's pocket. The taxpayer is in the like manner, entitled to be astute to prevent, so far as he honestly can, the depletion of his means by the Revenue.

This position has always been the position of the law. However, with the recent developments in international tax law and the attitude of multinational corporations in creating artificial structures for the purpose of shifting profits from high tax jurisdictions to low tax jurisdictions (tax havens); it is highly questionable whether this position can withstand the intense public criticism. This position is aptly captured by the statement of Margaret Hodge, a British MP, when questioning the tax paying morale of some multinationals (Starbucks, Amazon, and Google). Hodge stated; 'Yeah, we're not accusing you of being illegal; we're accusing you of being immoral.'11 The statement was made in response to Matt Brittin's (Vice President, Google UK) defence that their tax paying activities in the UK were legal and in compliance with the relevant UK tax laws. Although, the position is highly controversial; it is reflective of the emerging principle of 'tax morality.' We shall now turn to examine the two perspectives to the debate.

\subsection{The policy makers' perspective}

The position of the courts, over the years, has been reflective of the policy position on the tax planning activities of multinational corporations, i.e. these strategies are neither illegal nor necessarily immoral. However, that has not stopped policy makers from constantly seeking ways to provide solutions to the myriad of problems plaguing international tax law, such as; Base Erosion and

9 FBIR (n 6 above).

10 [1928] AC 217.

11 H Ebrahimi 'Starbucks, Amazon and Google accused of being "immoral"' https:// www.telegraph.co.uk/finance/personalfinance/tax/9673358/Starbucks-Amazonand-Google-accused-of-being-immoral.html (accessed 23 February 2017). 
Profit-Shifting (BEPS) and specifically double non-taxation. The efforts of policy makers to curb these problems have been on for close to a century. They began with the efforts of the League of Nations in the 1920 s to curb the problems of international juridical doubletaxation. This led to the emergence of a Uniform Model Tax Treaty. However, following the collapse of the League of Nations, the work was continued by the Organisation for European Economic Cooperation (OEEC) the OECD's predecessor. In the years that followed, a Model Tax Convention was developed by the OECD. The United Nations also delved into this area and emerged with the United Nations Model Tax Convention as well. It should be borne in mind that the structures that emerged from these treaties defined the residence/source basis for taxation which is in existence today. This helped to significantly abate the problems of international double taxation. Although this brought a new problem to light; international double non-taxation, as multinationals began exploiting the loopholes in the system to avoid paying taxes altogether or pay little tax in some cases.

However, with respect to the specific issues relating to BEPS; the OECD has been the most active. As a result, there have been efforts to tackle these issues by the various technical working groups at the OECD for years. Notable efforts of the OECD to combat this problem can be seen in: ${ }^{12}$

- a 1998 report on Harmful Tax Competition by countries and follow up work to curb harmful tax practices;

- work done between 1998 and 2006 addressing treaty abuse; and

- a directory of aggressive tax planning schemes that began in 2006 and is shared among tax administrators.

Tax policy experts in academia and parliaments of various countries have also contributed significantly to attempts at curbing the BEPS issue over the years through academic literature and legislative proposals. The underlying theme in the efforts of policy experts is the need for a long-lasting change. However, irrespective of the efforts over the years, only little has been achieved until recently when the G20 called on the OECD to produce a report on 'Base Erosion and Profit Shifting' (BEPS), which it published in February 2013 and which it followed up with an Action Plan in July of the same year. ${ }^{13}$ This OECD BEPS project eventually led to a final draft in 2015 which has the potential to change the future of international tax law for

12 MS Corwin 'Sense and sensibility: The policy and politics of BEPS' 134 https:// kpmg-us-inst.adobecqms.net/content/dam/kpmg/taxwatch/pdf/2014/bepscorwin-tillinghast-tn-100614.pdf (accessed 27 February 2017).

13 M Devereux \& J Vella 'Are we heading towards a corporate tax system fit for the 21st century?’ http://ssrn.com/abstract=2532933 (accessed 26 February 2017). 
decades to come. This sudden change was influenced by one thing only; the public and media outcry.

\subsection{The public/media perspective}

The public outcry and media coverage of issues in international tax law has reached astounding proportions in the last decade. This state of affairs was influenced largely by the global financial crisis and the austerity measures that were adopted in most advanced economies. Consequently, there emerged a growing sense of outrage by the public about the role of large multinationals (particularly in the financial services industry) in triggering the crisis, and a heightened awareness and increasing sense of indignation as to whether multinationals were paying their "fair share of tax." 14 Nothing else better captures this public indignation than Margaret Hodge's infamous statement at the UK Parliament Public Accounts Committee. ${ }^{15}$

This public rage has been heightened by the activities of NGOs, politicians in countries where the debate is intense, public hearings, and the media. In Europe, the public responded with protests and boycotts, politicians responded with commitments to take immediate actions, and companies went into damage control mode. ${ }^{16}$ Undeniably, this politically charged environment fuelled by the public outcry has had its advantages. However, it must be noted that the demerits of mainstreaming this debate far outweighs the advantages. This is because, the new international tax regime that will emerge from this period needs clear and coordinated tax rules that cannot possibly be formulated by the raging public as they lack a clear understanding of the complexities of international tax rules and policies. For instance, try explaining to a reporter not familiar with tax rules why 'transfer pricing' is not in fact the name of an evil planning strategy conjured up by businesses and their advisors to avoid paying taxes, as opposed to simply the name given to prices charged between related parties that must be set based on a series of complex domestic and international rules which are themselves based on the arms-length standard. ${ }^{17}$

Furthermore, the emerging principle of 'tax morality' forces multinationals into desperate situations as they are more concerned with paying more taxes in jurisdictions where the criticism is harsher than in cooperating with the authorities to bring lasting changes. The concept of 'tax morality' also lacks clearly defined parameters as it is incapable of defining how much tax multinational corporations should 
pay and which jurisdictions should have the right to tax. Thus, the lack of understanding of these long-standing tax rules by the media/ public makes it impossible for them to be capable of bringing the desired changes and any change that emerges from this process will be at best poor and hastily conceived.

However, it is worthy of note that the media/public's involvement in this debate; if properly coordinated, has the potential to bring the desired change. This can be done through involving all the stakeholders; states, multinationals, NGOs and the media. This strategy will help avoid any unilateral action by States which has the potential to further obscure the rules and make them more complex. The only coordinated activity on the international scene thus far, that appears to be responding to the call for change in international tax rules and running on the energy of the media/public's involvement in the debate is the OECD's BEPS project. The next section shall examine the work of the OECD on BEPS in detail.

\section{The OECD BEPS project}

In light of the political tensions surrounding BEPS, the OECD claims that BEPS distorts competition - thus giving multinationals an advantage over local operations. ${ }^{18}$ It also claims that it results in economic inefficiency as investment decisions are made for tax (as opposed to commercial) reasons, and that it undermines voluntary compliance, as 'ordinary' taxpayers will see this advantage given to multinationals as being unfair. ${ }^{19}$ This led to its commissioning of the BEPS project. In July 2013, the G20 endorsed the BEPS project, and it identifies 15 key areas in order to address loopholes and gaps in the current domestic and international tax system. ${ }^{20}$ The objective of the BEPS Project is to close gaps in international tax rules, effectively eliminating or substantially reducing BEPS; and to secure government revenues by ensuring that profits are taxed in the jurisdiction where the economic activities generating such profits are performed and where value is created. ${ }^{21}$ The BEPS Project involves input from the 34 member countries of the OECD, all G20 members, and more than 40 developing countries. 22

B Ger 'South Africa: How will BEPS affect the 2014 budget?' http:// www.thesait.org.za/news/163983/South-Africa-How-will-BEPS-affect-the-2014budget.html (accessed 27 February 2017).

19 Ger (n 18 above).

20 Deloitte ( 2 above).

21 Brunto (n 7 above).

22 Brunto (n 7 above). 
On 5 October 2015, the OECD released final reports on all 15 focus areas of its Action Plan on BEPS. ${ }^{23}$ The BEPS Action Plans are;

(i) Action 1: Addressing the Tax Challenges of the Digital Economy;

(ii) Action 2: Neutralising the Effects of Hybrid Mismatch Arrangements;

(iii) Action 3: Designing Effective Controlled Foreign Company Rules;

(iv) Action 4: Limiting Base Erosion Involving Interest Deduction and Other Financial Payments;

(v) Action 5: Countering Harmful Tax Practices More Effectively, Taking Into Account Transparency and Substance;

(vi) Action 6: Preventing Granting of Treaty Benefits in Inappropriate Circumstances;

(vii) Action 7: Preventing the Artificial Avoidance of Permanent Establishment Status;

(viii) Actions 8-10: Aligning Transfer Pricing Outcomes with Value Creation;

(ix) Action 11: Measuring and Monitoring BEPS;

(x) Action 12: Mandatory Disclosure Rules;

(xi) Action 13: Transfer Pricing Documentation and Country-by-Country Reporting;

(xii) Action 14: Making Dispute Resolution Mechanisms More Effective; and

(xiii) Action 15: Developing a Multilateral Instrument to Modify Bilateral Tax Treaties.

We shall now briefly examine each of the OECD BEPS Action Plans.

\subsection{Action 1: Addressing the tax challenges of the digital economy}

The Task Force on the Digital Economy (TFDE), was established in September 2013 to develop a report identifying issues raised by the digital economy and detailed options to address them by September $2014 .^{24}$ This action plan sets out to identify the tax challenges that result from the digitalisation of many business models including increased digital presence without a physical taxable presence. ${ }^{25}$ Another problem of taxation that the TFDE identified in relation to the digital economy is with respect to the broader tax challenges for policy makers. This identified problems relating to Value Added Tax collection particularly where goods, services and intangibles are

$23 \mathrm{~J}$ Liebenberg \& M Hewson 'BEPS developments in Africa' http://www.ey.com/za/ en/newsroom/news-releases/news-ey-beps-developments-in-africa (accessed 27 February 2017).

24 OECD 'OECD/G20 base erosion and profit shifting project: Executive summaries 2015 final reports' https://www.oecd.org/ctp/beps-reports-2015-executivesummaries.pdf (accessed 27 February 2017).

25 PwC Nigeria 'Impact of the OECD BEPS project on companies operating in Nigeria' http://pwcnigeria.typepad.com/files/pwc-tax-alert_impacts-of-beps-onnigeria.pdf (accessed 27 February 2017). 
acquired by private consumers from suppliers abroad. ${ }^{26}$ In relation to this Action Plan, the OECD does not necessarily recommend a new set of tax rules for the digital economy. ${ }^{27}$ Rather it is believed that the recommendations from other action plans regarding changes to the Transfer Pricing Guidelines, Permanent Establishment (PE) definitions and Controlled Foreign Corporation (CFC) rules will help address the BEPS risks associated with the digital economy. ${ }^{28}$ The OECD also proposed that continuous work be carried out on these issues and that developments be monitored over time. It further proposed that future work will be carried out in conjunction with a broad range of stakeholders and that a report reflecting the future work to be carried out be produced by 2020 .

\subsection{Action 2: Neutralising the effects of hybrid mismatch arrangements}

The work of the OECD on this issue sets out to resolve BEPS issues, such as; double non-taxation and double deductions that result from hybrid entities or transactions. ${ }^{29}$ It defines Hybrid Mismatch Arrangements as arrangements that exploit differences in the tax treatment of an entity or instrument under the laws of two or more tax jurisdictions to achieve double non-taxation, including long-term deferral. ${ }^{30}$ A common example of a hybrid transaction is an instance where the return on a financial investment escapes tax in the country of the investor and investee entities because it qualifies as deductible interest in the paying jurisdiction but is treated as non-taxable dividend in the receiving jurisdiction. ${ }^{31}$ In addressing the problems under this Action Plan, the OECD divided its report into two Parts. Part one contains recommendations for changes to domestic tax law in order to effectively tackle the issue, while part two sets out recommended changes to the OECD Model Tax Convention.

\subsection{Action 3: Designing effective controlled foreign company rules}

Controlled foreign company (CFC) rules respond to the risk that taxpayers with a controlling interest in a foreign subsidiary can strip the base of their country of residence and, in some cases, other countries by shifting income into a CFC. ${ }^{32}$ With respect to the OECD's work under this Action Plan, it sets out recommendations in the form

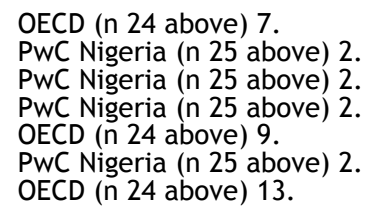


of building blocks. The recommendations do not seek to create minimum standards but to ensure that jurisdictions who seek to implement them are able to effectively prevent Companies from shifting profits to foreign subsidiaries. The report has six recommendations which it describes as the six building blocks for effective CFC rules. The recommendations are as follows;

(i) With respect to the definition of CFC, it provides recommendations on how best to determine when shareholders have sufficient influence over a foreign company for it to qualify as a CFC. It also provides recommendations on how non-corporate entities and their income should be brought within CFC rules; ${ }^{33}$

(ii) With respect to CFC exemptions and threshold requirements, the report recommends that CFC rules only apply to controlled foreign companies that are subject to effective tax rates that are meaningfully lower than those applied in the parent jurisdiction; ${ }^{34}$

(iii) With respect to the definition of income, the report recommends that CFC rules include a definition of CFC income, and it sets out a non-exhaustive list of approaches or combination of approaches that CFC rules could use for such a definition; ${ }^{35}$

(iv) With respect to the computation of income, the report recommends that CFC rules use the rules of the parent jurisdiction to compute the CFC income to be attributed to shareholders. It also recommends that CFC losses should only be offset against the profits of the same CFC or other CFCs in the same jurisdiction; ${ }^{36}$

(v) With respect to the attribution of income, the report recommends that, when possible, the attribution threshold should be tied to the control threshold and that the amount of income to be attributed should be calculated by reference to the proportionate ownership or influence; ${ }^{37}$ and

(vi) With respect to prevention and elimination of double taxation, the report emphasises the importance of both preventing and eliminating double taxation, and it recommends, for example, that jurisdictions with CFC rules allow a credit for foreign taxes actually paid, including any tax assessed on intermediate parent companies under a CFC regime. It also recommends that countries consider relief from double taxation on dividends on, and gains arising from the disposal of, CFC shares where the income of the CFC has previously been subject to taxation under a CFC regime. ${ }^{38}$ 


\subsection{Action 4: Limiting base erosion involving interest deduction and other financial payments}

It is common practice for multinationals to achieve favourable tax results by adjusting the amount of debt in a group entity. This can easily be done by multiplying the level of debt at the level of individual group entities via intra-group financing. Financial instruments can also be used to make payments which are economically equivalent to interest but have a different legal form, therefore escaping restrictions on the deductibility of interest. ${ }^{39}$ BEPS risks in these areas can arise in three basic scenarios; Groups placing higher levels of third party debt in high tax countries; Groups using intragroup loans to generate interest deductions in excess of the group's actual third party interest expense; and Groups using third party or intragroup financing to fund the generation of tax exempt income. ${ }^{40}$ In addressing these issues, the recommended approach is based on a fixed ratio rule which limits an entity's net deductions for interest and payments economically equivalent to interest to a percentage of its earnings before interest, taxes, depreciation and amortisation (EBITDA) ${ }^{41}$ As a minimum this should apply to entities in multinational groups. ${ }^{42}$

\subsection{Action 5: Countering harmful tax practices more effectively, taking into account transparency and substance}

In addressing the issue of Harmful Tax Practices, the Forum on Harmful Tax Practices (FHTP) focused on agreeing and applying a methodology to define the substantial activity requirement to assess preferential regimes, looking first at intellectual property (IP) regimes and then other preferential regimes. ${ }^{43}$ The work has also focused on improving transparency through the compulsory spontaneous exchange of certain rulings that could give rise to BEPS concerns in the absence of such exchanges. ${ }^{44}$ In addressing the requirement of substantial activity for preferential regimes, the 'nexus approach' was recommended. This approach was developed in the context of IP regimes, and it allows a taxpayer to benefit from an IP regime only to the extent that the taxpayer itself incurred qualifying research and development (R\&D) expenditures that gave rise to the IP income. ${ }^{45}$ The nexus approach uses expenditure as a 
proxy for activity and builds on the principle that, because IP regimes are designed to encourage R\&D activities and to foster growth and employment, a substantial activity requirement should ensure that taxpayers benefiting from these regimes did in fact engage in such activities and did incur actual expenditures on such activities. ${ }^{46}$ This same principle can also be applied to other preferential regimes so that such regimes would be found to require substantial activities where they grant benefits to a taxpayer to the extent that the taxpayer undertook the core income-generating activities required to produce the type of income covered by the preferential regime. ${ }^{47}$

Furthermore, in the area of transparency, a framework covering all rulings that could give rise to BEPS concerns in the absence of compulsory spontaneous exchange has been agreed. ${ }^{48}$ The framework covers six categories of rulings: (i) rulings related to preferential regimes; (ii) cross border unilateral advance pricing arrangements (APAs) or other unilateral transfer pricing rulings; (iii) rulings giving a downward adjustment to profits; (iv) permanent establishment (PE) rulings; ( $v$ ) conduit rulings; and (vi) any other type of ruling where the FHTP agrees in the future that the absence of exchange would give rise to BEPS concerns. ${ }^{49}$ Best Practices for cross-border rulings are also set out in the report.

\subsection{Action 6: Preventing granting of treaty benefits in inappropriate circumstances}

This Action Plan identifies treaty shopping and treaty abuse as some of the most important sources of BEPS concerns. ${ }^{50}$ Taxpayers engaged in treaty shopping and other treaty abuse strategies undermine tax sovereignty by claiming treaty benefits in situations where these benefits were not intended to be granted, thereby depriving countries of tax revenues. ${ }^{51}$ The report includes new treaty anti-abuse rules that provide safeguards against the abuse of treaty provisions and offer a certain degree of flexibility regarding how to do so. ${ }^{52}$ These new treaty anti-abuse rules first address treaty shopping, which involves strategies through which a person who is not a resident of a State attempts to obtain benefits that a tax treaty concluded by that State grants to residents of that State, for example by establishing a letterbox company in that State. ${ }^{53}$ The recommended approach to tackling these issues are through; the creation of a Limitations-on-

46 As above.

47 As above.

48 OECD (n 24 above) 20.

49 As above.

50 OECD (n 24 above) 21.

51 As above.

52 As above.

53 As above. 
Benefits (LOB) Rule ${ }^{54}$ and the inclusion of the rule in the OECD Model Tax Convention; an inclusion of the Principal Purposes Test (PPT) in the OECD Model Tax Convention to cover cases not covered by the PPT test.

\subsection{Action 7: Preventing the artificial avoidance of permanent establishment status}

As a result of the strategy employed by multinationals to avoid the payment of taxes through the existing loopholes in the definition of; 'Permanent Establishment,' the BEPS Action Plan recommended an amendment to the definition to avoid shifting profit out of the jurisdiction where the profit was derived through the loopholes in the definition. Multinationals usually achieve this objective through the creation of so-called commissionaire arrangements. These are arrangements through which a person sells products in a State in its own name but on behalf of a foreign enterprise that is the owner of these products. ${ }^{55}$ This Action Plan makes recommendations to address; artificial avoidance of permanent establishment status through commissionaire arrangements and similar strategies; artificial avoidance of permanent establishment status through the specific exceptions in Article 5(4) of the OECD Model Tax Treaty; other strategies for the artificial avoidance of permanent establishment status; and follow-up, including on issues related to attribution of profits to permanent establishments. With regards to the first recommendation, changes are to be made to the existing definition of permanent establishment status to ensure as a matter of policy that intermediaries that conclude contracts on behalf of a foreign enterprise are deemed to have a taxable presence unless they are carrying out independent business. ${ }^{56}$ The second recommendation also ensures that multinational enterprises only enjoy the exceptions to permanent establishment status contained in Article 5 (4) of the OECD Model Tax Treaty when they are of a 'corollary or auxiliary nature.' It also recommends the Principal Purposes Test to ensure that the practice of splitting-up contracts between closely related parties to shift profits is effectively managed and avoided.

\subsection{Actions 8-10: Aligning transfer pricing outcomes with value creation}

Actions eight to ten target the misapplication of the existing international standards for transfer pricing, to ensure that transfer 
pricing outcomes are aligned with value creation. ${ }^{57}$ It stressed the arm's length principle used by many countries has proven useful as a practical and balanced standard for tax administrations and taxpayers to evaluate transfer prices between associated enterprises, and to prevent double taxation. However, with its perceived emphasis on contractual allocations of functions, assets and risks; the existing guidance on the application of the principle has also proven vulnerable to manipulation. This manipulation can lead to outcomes which do not correspond to the value created through the underlying economic activity thus the guidance on the arm's length principle to be clarified and strengthened. Furthermore, if transfer pricing risks remain after clarifying and strengthening the guidance, the BEPS Action Plan foresaw the possibility of introducing special measures either within or beyond the arm's length principle.

The plan focused on three key areas. Work under Action eight looked at transfer pricing issues relating to transactions involving intangibles, since misallocation of the profits generated by valuable intangibles has contributed to base erosion and profit shifting. ${ }^{58}$ Action nine considered the contractual allocation of risks, and the resulting allocation of profits to those risks, which may not correspond with the activities actually carried out. ${ }^{59}$ It also addressed the level of returns to funding provided by a capital-rich multinational enterprises (MNEs) group member, where those returns do not correspond to the level of activity undertaken by the funding company. ${ }^{60}$ Action ten focused on other high-risk areas, like; the scope for addressing profit allocations resulting from transactions which are not commercially rational for the individual enterprises concerned, the scope for targeting the use of transfer pricing methods in a way which results in diverting profits from the most economically important activities of the MNE group, and neutralising the use of certain types of payments between members of the MNE group to erode the tax base in the absence of alignment with value creation. ${ }^{61}$

\subsection{Action 11: Measuring and monitoring BEPS}

Action eleven proposes the establishment of methodologies to gather and analyse data on BEPS. This Action Point aims to monitor and examine the effectiveness and economic impact of the action points. It also analyses all the problems associated with BEPS which the current available data provides. In light of this, the Action Plan makes recommendations that will improve the analysis of available data. It 
states that some of the information that is needed to improve the measurement and monitoring of BEPS is already collected by tax administrations, but not analysed or made available for analysis. ${ }^{62}$ The focus of the report's recommendations in this area is on improved access to and enhanced analysis of existing data, and new data proposed to be collected under Actions five, thirteen and, where implemented, Action twelve of the BEPS Project. ${ }^{63}$

The report finally recommends that in order to effectively address this issue, the OECD should work with governments to report and analyse more corporate tax statistics and present them in a way that is internationally consistent. ${ }^{64}$ The goal of this Action Point is to enable future researchers and Governments to be able to effectively, analyse and tackle the problems posed by BEPS.

\subsection{Action 12: Mandatory disclosure rules}

Action twelve identified the lack of timely, comprehensive and relevant information on aggressive tax planning strategies as a major problem faced by tax authorities worldwide. Early access to such information provides the opportunity to quickly respond to tax risks through informed risk assessment, audits, or changes to legislation or regulations. ${ }^{65}$ It recognised the benefits of tools designed to increase the information flow on tax risks to tax administrations and tax policy makers. It therefore called for recommendations regarding the design of mandatory disclosure rules for aggressive or abusive transactions, arrangements, or structures taking into consideration the administrative costs for tax administrations and businesses; and drawing on experiences of the increasing number of countries that have such rules. ${ }^{66} \mathrm{~A}$ modular framework that enables countries without mandatory disclosure rules to design a regime that fits their need to obtain early information on potentially aggressive or abusive tax planning schemes and their users was provided for.

\subsection{Action 13: Transfer pricing documentation and country-by- country reporting}

This report contains revised standards for transfer pricing documentation and a template for Country-by-Country Reporting of income, taxes paid and certain measures of economic activity. This Action Plan requires the development of 
[R]ules regarding transfer pricing documentation to enhance transparency for tax administration, taking into consideration the compliance costs for business. The rules to be developed will include a requirement that multinational enterprises (MNEs) provide all relevant governments with information on their global allocation of the income, economic activity and taxes paid among countries according to a common template. ${ }^{67}$

In response to this requirement, a three-tiered standardised approach to transfer pricing documentation has been developed. First, the guidance on transfer pricing documentation requires MNEs to provide tax administrations with high-level information regarding their global business operations and transfer pricing policies in a 'master file' that is to be available to all relevant tax administrations. 68 Second, it requires 'a local file' specific to each country, identifying material related party transactions, the amounts, and the company's analysis of the transfer pricing determinations they have made with regard to those transactions. ${ }^{69}$ Third, large MNEs are required to file an annual Country-by-Country Report that will provide for each tax jurisdiction in which they do business; the amount of revenue, profit before income tax and income tax paid and accrued among others. ${ }^{70}$ These three documents (master file, local file and Country-by-Country Report) should make it easier for tax administrations to identify whether Companies have engaged in transfer pricing and other practices that have the effect of artificially shifting substantial amounts of income into tax-advantaged environments.

\subsection{Action 14: Making dispute resolution mechanisms more effective}

Countries agreed that the introduction of the measures developed to address Base Erosion and Profit Shifting pursuant to the Action Plan on Base Erosion and Profit Shifting (BEPS Action Plan, OECD, 2013) should not lead to unnecessary uncertainty for compliant taxpayers and to unintended double taxation. Improving Dispute Resolution mechanisms is therefore an integral component of the work on BEPS issues. $^{71}$

Article 25 of the OECD Model Tax Convention (OECD, 2014) provides for the Mutual Agreement Procedure (MAP) - a mechanism, independent from the ordinary legal remedies available under domestic law, through which the competent authorities of the Contracting States may resolve differences or difficulties regarding 
the interpretation or application of the Convention on a mutuallyagreed basis. ${ }^{72}$ This ensures that taxpayers entitled to the benefits of the Treaty are not subject to taxation by either of the Contracting States. The measures developed under Action 14 of the BEPS Action Plan aim to strengthen the effectiveness and efficiency of the MAP process. They aim to minimise the risks of uncertainty and unintended double taxation by ensuring the consistent and proper implementation of tax treaties, including the effective and timely resolution of disputes regarding their interpretation or application through the mutual agreement procedure. ${ }^{73}$ Through the adoption of this Report, countries have agreed to important changes in their approach to dispute resolution, in particular by having developed a minimum standard.

\subsection{Action 15: Developing a multilateral instrument to modify bilateral tax treaties}

Action fifteen provides for an analysis of the tax and public international law issues related to the development of a multilateral instrument to enable countries that wish to do so to implement measures developed in the course of the work on BEPS and amend bilateral tax treaties. ${ }^{74}$ Using the analysis, interested countries will develop a multilateral instrument designed to provide an innovative approach to international tax matters, reflecting the rapidly evolving nature of the global economy and the need to adapt quickly to this evolution. The goal is to streamline the implementation of the tax treaty-related BEPS measures. This is an innovative approach is unprecedented. ${ }^{75}$

The 2014 Report, was cited as it explored the technical feasibility of a multilateral hard law approach and its consequences on the current tax treaty system. It identified the issues arising that could emanate from such an instrument, providing an analysis of the international tax, public international law, and political issues that arise from such an approach. It also concluded that a multilateral instrument is desirable and feasible, and that negotiations for such an instrument should be convened quickly. A mandate for the formation of a voluntary ad hoc group (the Group) to develop a multilateral instrument on tax treaty measures to tackle BEPS, was approved by the OECD Committee on Fiscal Affairs and endorsed by the G20 Finance Ministers and Central Bank Governors in February 2015. 


\section{Impact of the OECD BEPS project on Africa}

The OECD BEPS Project has the potential to reform the international corporate tax system for centuries to come. In light of this fact, countries have begun to restructure their corporate tax systems to meet the recommendations emanating from the OECD BEPS Project. The African continent is falling in line to achieve this much needed change to the tax planning strategy of multinationals. This part of the paper shall analyse the effects of BEPS on the African continent and the impact of the OECD BEPS Project on Africa.

\subsection{Effect of BEPS on Africa}

The tax planning strategy of multinationals which has formed the crux of the work of the OECD significantly affects the revenue base of many African states. This is due to the fact that most African states rely heavily on corporate tax income. ${ }^{76}$ Corporate tax income has been estimated to account for more than $25 \%$ of total revenue in African states. The resultant effect of this is a loss in corporate tax revenue caused by BEPS related activities. Another important issue BEPS raises in Africa is the issue of illicit financial flows. ${ }^{77}$ The term generally implies the movement of money in a way that contravenes the laws or regulations of a country. ${ }^{78}$ Such movements of money can be a product of illegal activities, such as tax evasion, organised crime, customs fraud, money laundering, terrorist financing and bribery. However, some controversial definitions of illicit financial flows may include; certain corporate tax-avoiding practices, such as BEPS, which are legal. ${ }^{79}$ Reports by the Global Financial Integrity estimates that tax and illicit capital flight from Africa is between $\$ 50$ billion and $\$ 80$ billion per annum, and in some cases revenue lost exceeds the level of aid received. ${ }^{80}$

Interestingly, it is worthy of note that although; civil society organisations have equated BEPS to illicit financial flows and the activity itself negatively affects revenue collection in Africa, both terms are in principle, different. This is due largely to the inaccuracy

$7670 \%$ of the corporate tax income of Rwanda comes from multinationals. This figure is as high as $88 \%$ in Nigeria and $20 \%$ in Burundi. See; A Mathur, 'Why $70 \%$ of Companies paid zero in corporate taxes' https://www.forbes.com/sites/ aparnamathur/2016/04/20/why-70-of-company-paid-zero-in-corporate-taxesthey-had-zero-profits/\#a288fbe56e36 (accessed 19 October 2017)

77 R Baker Capitalism's Achilles heel: Dirty money and how to renew the freemarket system (2005) 25.

78 AW Oguttu 'Tax base erosion and profit shifting in Africa - part 1: Africa's response to the OECD BEPS action plan' http://www.ictd.ac/publication/2working-papers/127-tax-base-erosion-and-profit-shifting-in-africa-part-1-africas-response-to-the-oecd-beps-action-plan (accessed 21 July 2017) 13.

80 Oguttu (n 78 above) 14. 
of the assertion in light of international tax law norms. Whilst, BEPS is a result of perceived weakness in international tax laws, coupled with lack of administrative capacity to fully assess and audit international tax risks that are exploited by MNEs; illicit financial flows are a result of a wide range of illegal flows of money, such as from organised crimes, money laundering, terrorist financing, bribery and customs fraud. ${ }^{81}$ Thus, equating BEPS with illicit financial flows fosters confusion in understanding international tax principles, and in finding solutions to the problem of capital flight. ${ }^{82}$

This notwithstanding, BEPS undermines the integrity of the tax system, raises concerns about tax morality and also affects the morale of the tax payers and their compliance rate. The adverse effect of this is that it leads to serious underfunding of public projects in Africa. The situation with BEPS is influenced by a number of factors which include, lack of relevant international tax laws or an unclear understanding of how the laws work and limited administrative capacity, etc. ${ }^{83}$

In light of the dire situation with BEPS in Africa and the developing world in general, concerns have been raised about the level of involvement of Africa in the OECD BEPS Project and whether the continent is reacting to the ongoing changes in international tax law. The next part of this paper shall address the impact of the OECD BEPS Project in Africa.

\subsection{The impact of the OECD BEPS project on Africa}

The OECD Action Plan noted in 2013 that in order to achieve a consensus with the BEPS Project, it will be important to take the concerns of developing countries into consideration. In this light, regional bodies such as the African Tax Administration Forum (ATAF) have been reacting positively to the Action Plans released by the OECD. 84

In March of 2014, the African Tax Administration Forum held a conference in Johannesburg on the Global Tax Agenda for heads of African tax administrations and Ministries of Finance. The participants from 29 African countries and OECD officials deliberated on the 'New Rules of the Global Tax Agenda' and the G20/OECD-driven project on BEPS, and considered an African response to these developments. 85 The ATAF noted that the development of rules for global taxation should address the concerns of all countries and that it should be

\footnotetext{
Oguttu (n 78 above) 15.

As above.

Oguttu (n 78 above) 15.

As above.

Oguttu (n 78 above) 22.
} 
inclusive, to ensure that the international tax rules can be applied effectively by developed, emerging and developing countries. ${ }^{86}$ ATAF recognized that a lot to be done to improve; administrative capacity, broaden the tax base, and increase tax revenue in Africa as a proportion of GDP. ${ }^{87}$ Consequently, it made a commitment to facilitate African participation in the Global Tax Agenda, and to put in place structures to enable on-going dialogue about BEPS on the continent and internationally. To this end, ATAF developed an African Work Plan on the Global Tax Agenda, for which a 'Cross-Border Taxation Technical Committee' was established to provide guidance on an African BEPS approach and to give input into the OECD BEPS process. ${ }^{88}$

Furthermore, in April of 2015 in Johannesburg, the ATAF convened another conference on 'Cross-Border Taxation in Africa.' 89 The conference focused on an African position on the BEPS Action Points, and on providing African countries an opportunity to define the baseeroding practices that are most relevant to Africa. ${ }^{90}$ The South African Minister of Finance remarked at the Conference that it was time for the African Continent to establish a Tax Policy and Tax Administration Commission which he claims is missing within the structure of the African Commission.

Apart from the regional efforts, the Revenue and Tax Authorities of different African Countries have also begun to implement the OECD BEPS Action Plan. Nigeria has responded positively, especially in the area of Transfer Pricing. This is due to the fact that the Nigerian Federal Inland Revenue Service (FIRS) has followed OECD BEPS Project closely and has contributed to its development through the ATAF. The Nigerian tax authorities have commenced a painstaking review of companies' Transfer Pricing policies and compliance documentation. ${ }^{91}$ The process also involves interviewing taxpayers' officers that perform key functions in the related party transactions. Some of the short and long term impacts of the OECD BEPS Project are; immediate application of changes to the OECD Guidelines since Regulation 11 of the Nigerian Transfer Pricing Regulations allows changes to the OECD Guidelines to automatically apply; ${ }^{92}$ potential legislative and regulatory amendments to incorporate other

86 As above.

87 As above

88 As above.

89 As above.

90 As above.

91 KPMG 'Base erosion and profit shifting: Explanatory note and implications for Nigeria' https://home.kpmg.com/content/dam/kpmg/pdf/2015/11/tnf-nigeriabeps-nov18-2015.pdf (accessed 21 July 2017).

92 PwC Nigeria "Impacts of the OECD BEPS project on companies operating in Nigeria” http://pwcnigeria.typepad.com/files/pwc-tax-alert_impacts-of-bepson-nigeria.pdf (accessed 21 July 2017). 
recommendations which are not part of the OECD Guidelines; ${ }^{93}$ increased scrutiny of preferential tax regimes and tax incentives provided to Nigerian businesses with a view to establishing instances where they have been granted inappropriately as well as whether the provision of those incentives provide any real economic benefit to the country; ${ }^{94}$ an increase in the demand (by the FIRS) for financial and other information of offshore related parties. This could include demands made to the local subsidiary (e.g. master file information) as well as demands made to the tax authorities of the Head Office (e.g. Country-by-Country reports) or non-resident affiliate through the mechanisms of the Convention on Mutual Administrative Assistance in Tax Matters; ${ }^{95}$ increase in transfer pricing audits and more focus on substance in evaluating the appropriateness of transfer prices; ${ }^{96}$ increase in the ability of the FIRS to identify and challenge instances of abusive transfer pricing. ${ }^{97}$

\section{Conclusion and recommendations}

An analysis of the OECD BEPS Project and its impact on Africa reveals that although Africa seems to be responding positively to the Action Plans proposed by BEPS (both regionally and individually), a lot still has to be done in relation to other areas. Action one of the OECD BEPS Project which deals with taxing the digital economy is yet to receive the attention it deserves in Africa. This poses a major challenge due to the fact that the tech revolution going on in Africa has led to the establishment of online businesses in their tens of thousands. The writer proposes that this problem should be addressed by African Countries through the establishment of a comprehensive indirect tax regime, in light of the recommendations proposed by the OECD.

Furthermore, the approach adopted by the Nigerian Transfer Pricing Regulations which makes changes to the OECD Transfer Pricing Guidelines to apply automatically should be adopted by other African Countries. The writer also recommends that the ATAF should create a framework which would ensure that the revenue authorities (in conjunction with the Legislature) of the various African states create policies to ensure that the Country-by-Country Reporting is effective. This would also require that the revenue authorities actively compile the relevant fiscal data of Multinational Corporations operating within their jurisdictions and make them readily available.

93 PwC Nigeria (n 91 above).

94 As above.

95 As above.

96 As above.

97 As above. 
Finally, although major public outcries which have plagued Europe and North America in relation to the fairness of international tax law rules are yet to hit Africa, it is proposed that the various revenue administrators in Africa, under the auspices of the ATAF should try to tackle these issues in a proactive manner through the strategies proposed in this paper. 